\title{
高層平面フレームの近似振動解析
}

\section{AN APPROXIMATE VIBRATION ANALYSIS OF HIGH-RISE PLANE FRAMES}

\author{
千葉正裕*, 倉田光春**, 池田昭男** \\ Masahiro CHIBA, Mitsuharu KURATA and Akio IKEDA
}

\begin{abstract}
This paper proposes a new method for reducing the degree-of-freedom and node in vibration analysis of high-rise plane frames in earthquakes. A theory of the reduction of stiffness and mass matrices in the equation of motion is also established for the proposed method. A finite element model reducing the degree-of-freedom and node by the method are analyzed. The analyzed results of the deformation and member forces of the model are approximate to the exact solution. In conclusion, the proposed method is available for the approximate vibration analysis of high-rise buildings.
\end{abstract}

Keywords : vibration analysis, finite element method, reduction of dynamic matrices, earthquake response

振動解析, 有限要素法, 動的マトリックス縮小, 地震応答

\section{1. 序 諞}

近年，敷地の制約や使用目的などにより，平面形・立 面形が複雑な建物や不連続な剛性および強度分布を持つ 建物が多くなってきている。また，鉄筋やコンクリート の高強度化，施工技術の向上に伴い，超高層鉄筋コンク リート造建物などか数多く建設されている。このような 建物の振動性状を忠実に把握することは, 簡便なモデル による振動解析では難しく，かつ部材レベルでの詳細な 変形状態および応力状態を把握することはできない。ま た, 許容応力度設計法から終局強度型設計法へと移行し つつある現在では，地震時における各部材の詳細な応力 状態を把握することが必要であり，急務となっている。

一方, 有限要素モテルを用いた振動解析は, 建物の詳 細な振動性状の把握を可能にするものであるが，未知数 が膨大になるため, 解析が非常に困難になる。

既往の論文では，骨組構面を薄板あるいは立体高層骨 組を 1 本の薄肉はりなどの連続体に置換し，未知数の低
減が行われている。例えば, 富沢と小西 ${ }^{1121}$ は, 武藤の $D$ 值法を拡張し，柱の伸縮を考慮したラーメンを薄板に， 加藤 ${ }^{4}$ は，骨組をエネルギー的に等価な連続体に置換し ている。また, 日置 ${ }^{5)}{ }^{6)}$ らは, 耐震壁を含む高層架構を 1 本の棒に置換している。最近では, 藤井と藤谷 ${ }^{71.8)}$ が 立体高首骨組を 1 本の薄肉はりに置換している。しかし， 建物の局部的な変形を連続体で精度よく置換することは 難しく，そのためには連続体の変形仮定が複雑となる。 連続体置換とは別に, 加藤 ${ }^{2)}$ らは, 有限要素法を用いた 骨組構面の一部を取り出し, 各節点変位をエネルギー的 に等価な代表節点の変位に置換し，未知数の低減を行っ ている。これは，建物の局部的な変形が，建物の主要な 変形に対して影響が少ないと仮定することにより可能と なる。また, Guyanの静的縮小法 ${ }^{10) \cdot 11)}$ は, 運動方程 式中の動的な項を無視することで未知数を低隇するもの であるが，その適用によっては，誤差を多く含む結果と なる。したがって, 既往の論文では, 層レベルでの変形

\footnotetext{
本諭文の一部は，参考文献12），15）１7）で発表している。

* 日本大学工学部建築学科 講師. 工修

** 日本大学工学部建築学科 教授. 工博
}

Lecturer, Dept. of Architecture, College of Engineering, Nihon Univ., M. Eng.

Prof., Dept. of Architecture, College of Engineering, Nihon Univ., Dr. Eng. 
および応力に対しては，比較的よい精度が得られている が, 部材レベルでの変形および応力に対しては, よい精 度が得られていない。

以上の背景を踏まえて, 本論文では，運動方程式中の 動的な項を無視することなく，建物の局部的な変形を精 度よく低減できる『動的縮小法』を提案する。さらに建 物の挙動を支配する主要な変形に対しては, 簡単な変形 仮定のモードで置換し，未知数を低減するものである。 この 2 つの方法を組み合わせることにより，大幅な未知 数の低減が可能となり, 精度のよい簡便な解析法となる。 なお, 本解析法は未知数の低減が行える之同時に, 低減 されたモデルの解析結果を低隇前の全未知数まで復元す ることが可能である。

本解析法は, 建物の立体振動解析に適用すへく開発し たものである。しかし, 本論文では簃密解との比較が可 能な高層平面フレームモデルに対してその有効性を検討 する。なお，高層平面フレームモデルにおける梁および 柱部材は, 全て有限要素法に基づく線材要素とし, 剛性 に関する要素の変形は, 軸変形および曲げ変形, 質量に 関しては，分布質量を用いた。この線材要素で組まれた 高層平面フレームモデルの全未知数に対して, 振動解析 した結果を厳密解とする。これに対し，動的縮小法およ びモード置換を用いて未知数を低隇したモデルの振動解 析結果を近似解之する。振動解析は，固有值解析，地震 応答解析および地震時応力解析とし, 部材レベルにおけ る変形および応力について精度検討を行う。

\section{2. 動的縮小法 ${ }^{12)}$}

\section{1 主变位に閣する運動方程式}

一般に運動方程式は(1)式で表され，主変位を $\ddot{\delta}_{1} ， \dot{\delta}_{1}$, $\delta_{1}$, 従変位を $\ddot{\delta}_{2}, \dot{\delta}_{2}, \delta_{2}\left(\right.$ ただし, $\ddot{\delta}_{1} \gg \ddot{\delta}_{2}, \dot{\delta}_{1} \gg \dot{\delta}_{2}$, $\left.\delta_{1} \gg \delta_{2}\right)$ とすると $(2)$ 式を得る。

$[M]\{\ddot{\delta}\}+[C]\{\dot{\delta}\}+[K]\{\delta\}=\{F\}$

ここに，[M]：質量マトリックス

$[C]$ : 減衰マトリックス

$[K]$ : 剛性マトリックス

$\{F\}$ : 外力ベクトル

$\{\ddot{\delta}\} ：$ 相対加速度ベクトル

$\{\dot{\delta}\}$ ：相対速度ベクトル

$\{\delta\} ：$ 相対変位ベクトル

$\left[\begin{array}{ll}M_{11} & M_{12} \\ M_{21} & M_{22}\end{array}\right]\left[\begin{array}{l}\ddot{\delta}_{1} \\ \ddot{\delta}_{2}\end{array}\right]+\left[\begin{array}{ll}C_{11} & C_{12} \\ C_{21} & C_{22}\end{array}\right]\left[\begin{array}{l}\dot{\delta}_{1} \\ \dot{\delta}_{2}\end{array}\right]+\left[\begin{array}{ll}K_{11} & K_{12} \\ K_{21} & K_{22}\end{array}\right]\left[\begin{array}{l}\delta_{1} \\ \delta_{2}\end{array}\right]$

$$
=-\left[\begin{array}{ll}
M_{11} & M_{12} \\
M_{21} & M_{22}
\end{array}\right]\left\{\begin{array}{l}
1 \\
0
\end{array}\right]\left\{\begin{array}{l}
\left.\ddot{\delta}_{0}\right\} \\
\} . . . .(2)
\end{array}\right.
$$

ここに, $\{\ddot{\delta} 0\}: 入 力$ 加速度ベクトル
(2)式の第 2 式より $\delta 2$ につて解き，時間 $t$ で 2 回および 1 回微分し, 時間 $t$ の 3 階以上の高階微分を含む項は, 他に対して十分小さいと仮定すると(3)式を得る。 $\ddot{\delta}_{2}=-K_{22} 2^{-1} K 21 \ddot{\delta}_{1}$ $\dot{\delta}_{2}=-K_{22}{ }^{-1}\left(C_{21} \ddot{\delta}_{1}+C_{22} \ddot{\delta}_{2}+K_{21} \dot{\delta}_{1}\right)$

(3)式の第 1 式を(3)式の第 2 式に，さらに(2)式の第 2 式に代入すると(4)式を得る。

$$
\left.\begin{array}{l}
\ddot{\delta}_{2}=-K_{22}{ }^{-1} K_{21} \ddot{\delta}_{1} \\
\dot{\delta}_{2}=-K_{22}{ }^{-1} \widetilde{C}_{2} \ddot{\delta}_{1}-K_{22}{ }^{-1} K_{21} \dot{\delta}_{1} \\
\delta_{2}=-K_{22}{ }^{-1}\left\{\left(\widetilde{M}_{2}-C_{22} K_{22}{ }^{-1} \widetilde{C}_{2}\right) \ddot{\delta}_{1}+\widetilde{C}_{2} \dot{\delta}_{1}+K_{21} \delta_{1}+M_{21} \ddot{\delta}_{0}\right\}
\end{array}\right\}
$$

$$
\text { ここに, } \begin{aligned}
\widetilde{M}_{2} & =M_{12}-M_{22} K_{22}{ }^{-1} K_{21} \\
\widetilde{C}_{2} & =C_{21}-C_{22} K_{22}{ }^{-1} K_{21}
\end{aligned}
$$

(4)式を(2)式の第 1 式に代入すると(5)式を得る。

$$
\bar{M} \ddot{\delta}_{1}+\bar{C} \dot{\delta}_{1}+\bar{K} \delta_{1}=\bar{F}
$$

$$
\begin{array}{ll} 
& \bar{C}=\widetilde{C}_{1}-K_{12} K_{22}{ }^{-1} \widetilde{C}_{2} \\
& \bar{K}=\widetilde{K}_{1} \\
& \bar{F}=-\widetilde{M}_{1}^{T} \ddot{\delta}_{0} \\
\text { ただし, } & \widetilde{M}_{1}=M_{11}-M_{12} K_{22}{ }^{-1} K_{21} \\
& \widetilde{M}_{1}^{T}=M_{11}-K_{12} K_{22}{ }^{-1} M_{21} \\
& \widetilde{C}_{1}=C_{11}-C_{12} K_{22} 2^{-1} K_{21} \\
& \widetilde{C}_{2}{ }^{T}=C_{12}-K_{12} K_{22}{ }^{-1} C_{22} \\
& \widetilde{K}_{1}=K_{11}-K_{12} K_{22}{ }^{-1} K_{21}
\end{array}
$$$$
\text { ここに, } \bar{M}=\widetilde{M}_{1}-K_{12} K_{22}{ }^{-1} \widetilde{M}_{2}-\widetilde{C}_{2}{ }^{T} K_{22}{ }^{-1} \widetilde{C}_{2}
$$

したがって，(5)式は主変位 $\ddot{\delta}_{1} ， \dot{\delta}_{1}, \delta_{1}$ に関する運動方程 式となる。

\section{2 従变位の誘迫}

(2)式の第 1 式より $\ddot{\delta}_{1}$ につて解き, 第 2 式に代入し, $\delta_{2}$ につて解く之(6)式を得る。

$$
\delta_{2}=\widetilde{K}_{3}{ }^{-1}\left(\widetilde{M}_{3} \ddot{\delta}_{2}+\widetilde{C}_{4} \dot{\delta}_{1}+\widetilde{C}_{3} \dot{\delta}_{2}+\widetilde{K}_{4} \delta_{1}\right)
$$

$$
=こ に, \quad \begin{array}{ll}
\widetilde{M}_{3} & =-M_{22}+M_{21} M_{11}^{-1} M_{12} \\
\widetilde{C}_{3} & =-C_{22}+M_{21} M_{11}{ }^{-1} C_{12} \\
\widetilde{C}_{4} & =-C_{21}+M_{21} M_{11}^{-1} C_{11} \\
\widetilde{K}_{3} & =K_{22}-M_{21} M_{11}{ }^{-1} K_{12} \\
\widetilde{K}_{4} & =-K_{21}+M_{21} M_{11}^{-1} K_{11}
\end{array}
$$

（6）式を時間 $t て ゙ ~ 4$ 回〜 1 回微分し, 時間 $t$ の 5 階以上の 高階微分を含む項は，他に対して十分小さいと仮定する と(7)式を得る。

$$
\left.\begin{array}{l}
\dddot{\delta}_{2}=\widetilde{K}_{3}{ }^{-1} \widetilde{K}_{4} \dddot{\delta}_{1} \\
\dddot{\delta}_{2}=\widetilde{K}_{3}^{-1}\left(\widetilde{C}_{4} \dddot{\delta}_{1}+\widetilde{C}_{3} \dddot{\delta}_{2}+\widetilde{K}_{4} \dddot{\delta}_{1}\right) \\
\ddot{\delta}_{2}=\widetilde{K}_{3}^{-1}\left(\widetilde{M}_{3} \dddot{\delta}_{2}+\widetilde{C}_{4} \dddot{\delta}_{1}+\widetilde{C}_{3} \dddot{\delta}_{2}+\widetilde{K}_{4} \ddot{\delta}_{1}\right) \\
\dot{\delta}_{2}=\widetilde{K}_{3}{ }^{-1}\left(\widetilde{M}_{3} \dddot{\delta}_{2}+\widetilde{C}_{4} \ddot{\delta}_{1}+\widetilde{C}_{3} \ddot{\delta}_{2}+\widetilde{K}_{4} \dot{\delta}_{1}\right)
\end{array}\right\}
$$


ここで， $\dddot{\delta}_{1} ， \dddot{\delta}_{1}$ は(5)式で求められた主変位 $\ddot{\delta}_{1}$ を用いて

(8)式に示す差分式より求められる。

$$
\left.\begin{array}{l}
\dddot{\delta}_{1}(t)=\frac{1}{2 \Delta t}\left\{\ddot{\delta}_{1}(t+\Delta t)-\ddot{\delta}_{1}(t-\Delta t)\right\} \\
\dddot{\delta}_{1}(t)=\frac{1}{2 \Delta t}\left\{\dddot{\delta}_{1}(t+\Delta t)-\dddot{\delta}_{1}(t-\Delta t)\right\}
\end{array}\right\}
$$

したがって, 従変位 $\ddot{\delta}_{2}, \dot{\delta}_{2}, \delta_{2}$ は(5)式で求められた主変 位 $\ddot{\delta}_{1} ， \dot{\delta}_{1}, \delta_{1}$ を用いて(6)式，(7)式より求められる。

\section{3. 平面梁モード ${ }^{22}$}

図一 1 に示すように平面梁材軸上任意点の材軸方向変 位 $u$ を $x$ の 1 次関数, たわみ方向変位 $v$ を $x$ の 3 次関数， 平面梁材軸の回転角 $\theta_{2}$ をたわみ $v$ の 1 階微分, 平面梁法 線の回転角を $\beta_{z}$ 亡し, せん断変形 $\left(\gamma=\theta_{z}+\beta_{z}\right)$ を $x$ の 1 次 関数で与えられるものとすると $(9)$ 式を得る。

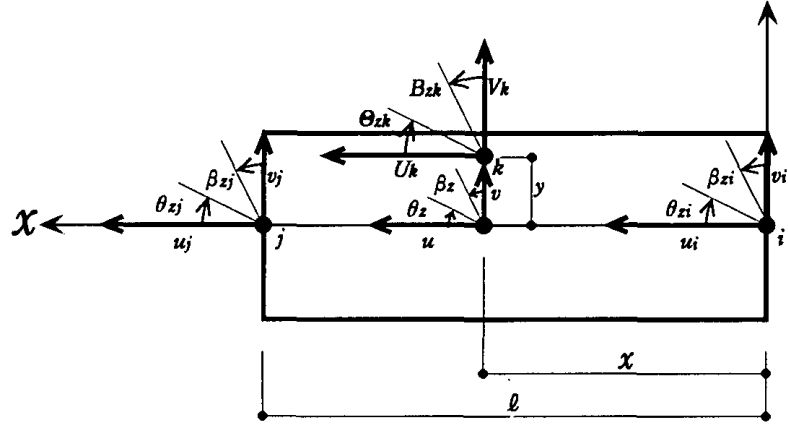

図一1 平面梁内任意節点梁位と平面梁材端節点変位

$$
\begin{aligned}
{\left[\begin{array}{l}
U_{k} \\
V_{k} \\
\Theta_{z k} \\
B_{z k}
\end{array}\right]=} & {\left[\begin{array}{llll}
1 & 0 & 0 & y \\
0 & 1 & 0 & 0 \\
0 & 0 & 1 & 0 \\
0 & 0 & 0 & 1
\end{array}\right]\left[\begin{array}{cccccccc}
1 & x & 0 & 0 & 0 & 0 & 0 & 0 \\
0 & 0 & 1 & x & x^{2} & x^{3} & 0 & 0 \\
0 & 0 & 0 & 1 & 2 x & 3 x^{2} & 0 & 0 \\
0 & 0 & 0 & -1 & -2 x & -3 x^{2} & 1 & x
\end{array}\right] } \\
& {\left[\begin{array}{llllllll}
1 & 0 & 0 & 0 & 0 & 0 & 0 & 0 \\
1 & \ell & 0 & 0 & 0 & 0 & 0 & 0 \\
0 & 0 & 1 & 0 & 0 & 0 & 0 & 0 \\
0 & 0 & 1 & \ell & \ell^{2} & \ell^{3} & 0 & 0 \\
0 & 0 & 0 & 1 & 0 & 0 & 0 & 0 \\
0 & 0 & 0 & 1 & 2 \ell & 3 \ell^{2} & 0 & 0 \\
0 & 0 & 0 & -1 & 0 & 0 & 1 & 0 \\
0 & 0 & 0 & -1 & -2 & -3 \ell^{2} & 1 & \ell
\end{array}\right] \quad\left[\begin{array}{l}
u i \\
u j \\
v i \\
v j \\
\theta_{z i} \\
\theta_{z j} \\
\beta_{z i} \\
\beta_{z j}
\end{array}\right] }
\end{aligned}
$$

ここに, $x, y$ は平面梁内任意節点 $k$ $~ x, y$ 方向座標値,

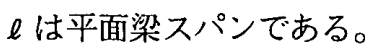

したがって, 平面梁内任意節点 $k$ の変位 $U_{k}, V_{k}, \Theta_{2 k}, B_{2 k}$ $(k=1,2, \cdots, n)$ は平面梁材端節点変位 $u i, u j, v i, v j, \theta_{z i}$, $\theta_{z j}, \beta_{z i}, \beta_{z j}$ で表すことができる。

\section{4. 解析モデル}

図ー 2 に示すように解析モデルは，床板の質量および

\begin{tabular}{|c|c|c|}
\hline \multicolumn{3}{|c|}{ 表一1 各部材断面寸法 } \\
\hline 部 材 & 階 & 断面寸法 (mm) \\
\hline \multirow{6}{*}{ 梁 } & "R階～21階 & $500 \times 750$ \\
\hline & 20階 16階 & $550 \times 750$ \\
\hline & 15階～11階 & $550 \times 800$ \\
\hline & 10階〜 6階 & $600 \times 800$ \\
\hline & 5階～3階 & $600 \times 900$ \\
\hline & 2階 & $600 \times 1000$ \\
\hline \multirow{3}{*}{ 柱 } & 25階～15階 & $800 \times 800$ \\
\hline & 14階～7階 & $850 \times 850$ \\
\hline & 6階～1階 & $900 \times 900$ \\
\hline 基礎梁 & 1階 & $900 \times 4500$ \\
\hline
\end{tabular}
剛性，部材の鉄筋を考虑しない純フレーム構造の 25 階 建鉄筋コンクリート造高層平面フレームモデルとした。

$\underline{\text { RSL }}$

$\underline{25 \mathrm{FL}}$

$24 \mathrm{FL}$

$\underline{23 \mathrm{FL}}$

$\underline{22 \mathrm{FL}}$

$\underline{21 \mathrm{FL}}$

$\underline{20 \mathrm{FL}}$

$19 \mathrm{FL}$

$\underline{18 \mathrm{FL}}$

$\underline{17 \mathrm{FL}}$

$16 \mathrm{FL}$

$\underline{15 \mathrm{FL}}$

$14 \mathrm{FL}$

$13 \mathrm{FL}$

$\underline{12 \mathrm{FL}}$

$\underline{11 \mathrm{FL}}$

$10 \mathrm{FL}$

$9 \mathrm{FL}$

$8 \mathrm{FL}$

7FL

$6 \mathrm{FL}$

$5 \mathrm{FL}$

$4 \mathrm{FL}$

$3 \mathrm{FL}$

$2 \mathrm{FL}$

$1 \mathrm{FL} \mathrm{GL}$
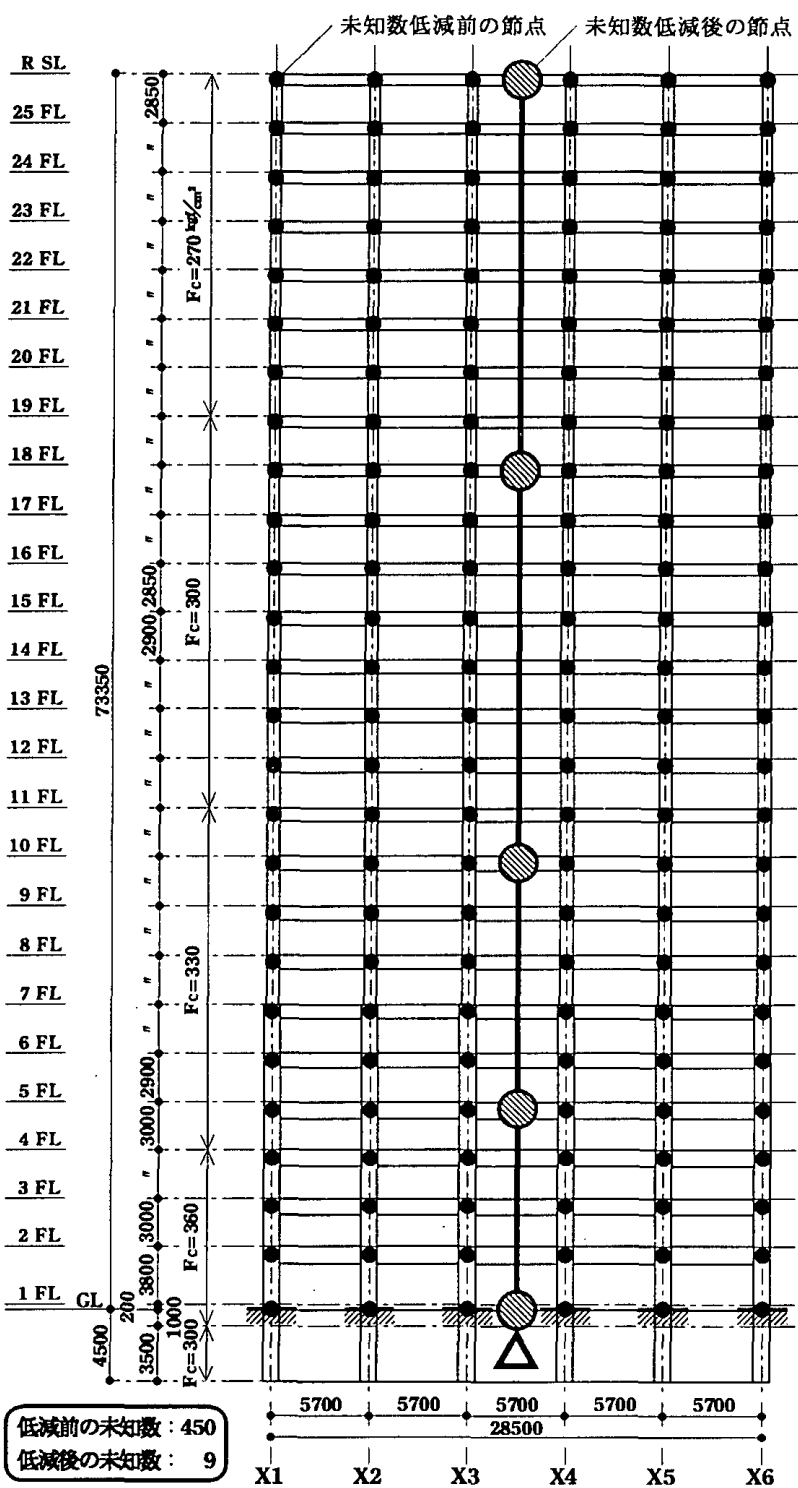

図-2 解析モテル 
表一 1 に各部材断面寸法を示す。コンクリートは高強度 コンクリートとし，設計基準強度を図ー 2 中に示す。各 部材の材料定数は, ポアソン比 $1 / 6$, 単位体積重量 2.4 $\mathrm{t} \mathrm{f} / \mathrm{m}^{3}$ とし，ヤング係数は，日本建築学会編「鉄筋コン クリート構造計算規準・同解説」 ${ }^{19)}$ に基づき算出した。

\section{5. 未知数の低減方法}

未知数の低隇は，図一 3 に示すように水平変位に関し ては，各層ごとにフレームの中央に代表節点を設け，各 層に存在する節点の水平変位 $V_{k l}$ を代表節点の水平変位 $\widetilde{V}_{k}$ と梁部材のひずみにより表現すると(10)式を得る。

$V_{k l}=\widetilde{V}_{k}+\sum_{m=0}^{1} \varepsilon_{k m} \ell k m \quad(l=-n,-n+1, \cdots,-1,1, \cdots, n-1, n)$

ここに, $V_{k l}: k$ 層 $l$ 節点における水平変位

$\widetilde{V}_{k}: k$ 層代表節点における水平変位

$\varepsilon_{k m}: k$ 層 $m-\frac{m}{|m|}$ 節点亡 $m$ 節点間のひずみ

$\ell k m: k$ 層 $m-\frac{m}{|m|}$ 節点と $m$ 節点間の材長

上下変位に関しては，各通りごとの最下層柱脚に代表 節点を設け，水平変位と同様に，各通りに存在する節点 の上下変位を柱部材のひずみにより表現する。これは， 従変位を動的縮小法で消去する際，変位レベルよりひず みレベルの方が主変位に対して十分小さくなるため，よ り精度が向上するからである。したがって，回転角の項 および各部材のひずみの項は，代表節点の水平変位の項
に対して十分小さくなると仮定し，動的縮小法により消 去する。次に，前述の平面梁モードを用いて，各層に存 在する代表節点の水平変位を平面梁材端節点変位で表し 未知数を低減する。なお，代表節点はフレームの中央す なわち平面梁材軸上に存在するため，(11)式に示すよう に(9)式のたわみ方向変位を用いることになる。したが って，(11)式に各層における代表節点の $x$ 方向座標値を 代入することにより, 各層の代表節点の水平変位 $\widetilde{V}_{\boldsymbol{k}}$ は, 平面梁材端節点変位 $v i, v j, \theta_{z i}, \theta_{z j}$ で表すことができ，未 知数が低減される。

$\widetilde{V}_{k}=\left[\begin{array}{llll}1 & x k & x k^{2} & x k^{3}\end{array}\right]\left[\begin{array}{cccc}1 & 0 & 0 & 0 \\ 1 & \ell & \ell^{2} & \ell^{3} \\ 0 & 1 & 0 & 0 \\ 0 & 1 & 2 \ell & 3 \ell^{2}\end{array}\right]^{-1}\left[\begin{array}{c}v i \\ v j \\ \theta_{z i} \\ \theta_{z j}\end{array}\right)$

ここに, $\quad \boldsymbol{\ell}:$ 平面梁材端の $i$ 節点と $j$ 節点間の距離

本解析モデルにおける未知数低減前のモデルは，各節 点ごとに水平変位, 上下変位および回転角の 3 自由度を 有している。したがって，低減前の未知数は 450 とな る。このモデル対して，前述のひずみによる表現およ び動的縮小法を用いて，未知数の低減を行うと，解析モ デルは各階の代表節点の水平変位で表され, 解析モデル 全体の未知数は 25 となる。さらに，図一 2 に示すよう に高次モードおよび境界の影響を考慮して 4 本の平面梁 モードで置換し，代表節点の水平変位を平面梁材端節点 変位で表し，5節点に低減する。したがって，低減後の 未知数は, 平面梁材端節点の水平変位および回転角の 9 となり，末知数低減前に対して $2 \%$ となる。

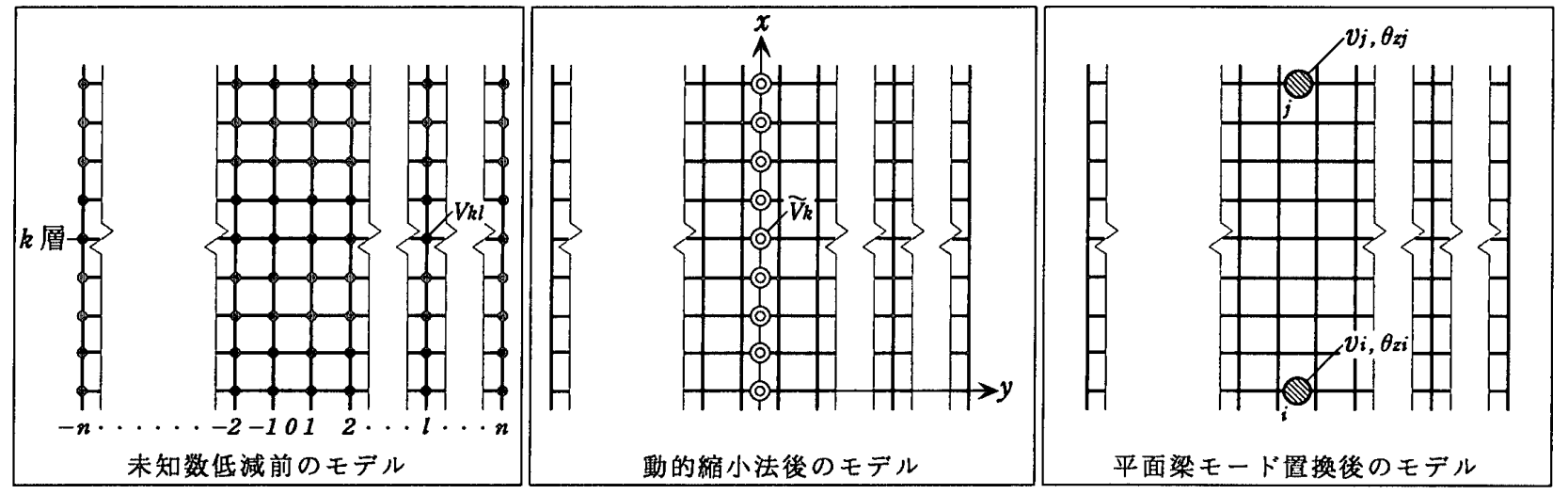

図一－3 未知数の低减モテル

\section{6. 解析結果}

\section{1 固有値解析}

固有值解析は，バイセクション法を用いて行い，未知 数低減前のモテルおよび未知数低減後のモテルの非減衰 自由振動方程式からそれぞれの固有周期を求めた。 表一 2 に厳密解および近似解の 1 次〜 4 次固有周期を示 す。高次で多少の相違が見られるが, よく一致している。
表一2 各次固有周期（秒）

\begin{tabular}{cc||c|c}
\hline 次 & 数 & 厳 密解 & 近 似解 \\
\hline \hline 1 & 次 & 0.820 & 0.820 \\
\hline 2 & 次 & 0.287 & 0.287 \\
\hline 3 & 次 & 0.165 & 0.164 \\
\hline 4 & 次 & 0.117 & 0.115 \\
\hline
\end{tabular}




\section{2 地震㡳答解析}

地震応答解析は，モーダルアナリシスによらず，時刻 歴の直接応答として, 線形加速度法を用いて行った。解 析時間間隔 $\Delta t$ は $1 / 1000$ 秒とし, 入力地震動のデー夕を線 形補間して解析に用いた。減衰は剛性に比例する内部粘 性減衰とし， 1 次固有振動数に対して，減衰定数を $5 \%$ とした。入力地震動 ${ }^{14)}$ は，設計によく用いられている EL CENTRO NS, TAFT EW, HACHINOHE NS, THO30-1FL NSの 4 種類を各部材の応力が弾性内にな るように最大加速度を $50 \mathrm{galに}$ 基準化して用いた。 以上の入力地震動を用い, 未知数低隇前のモデおよび 未知数低減後のモデルに対して解析を行い，全節点にお

\begin{tabular}{|c|c|c|c|c|}
\hline 地 & & 永平成分 & E下成乡 & 司転成分 \\
\hline \multirow{4}{*}{$\begin{array}{c}\text { EL CENTRO } \\
\text { NS }\end{array}$} & 絁対加速度 & 0.83 & ---- & ---- \\
\hline & 相対加速度 & 0.78 & 4.55 & 4.71 \\
\hline & 相対速度 & 0.79 & 0.05 & 3.40 \\
\hline & 相対変位 & 0.63 & 0.17 & 3.11 \\
\hline \multirow{4}{*}{$\begin{array}{l}\text { TAFT } \\
\text { EW }\end{array}$} & 絶対加速度 & 0.30 & $-\cdots$ & ---- \\
\hline & 相対加速度 & 0.80 & 0.95 & 3.56 \\
\hline & 相対速度 & 0.59 & 0.06 & 3.23 \\
\hline & 相対変位 & 0.63 & 0.12 & 3.18 \\
\hline \multirow{4}{*}{$\underset{\text { NS }}{\text { HACHINOHE }}$} & 絶対加速度 & 0.29 & $\ldots$ & ---- \\
\hline & 相対加速度 & 4.71 & 0.72 & 4.06 \\
\hline & 相对速度 & 0.74 & 0.17 & 3.43 \\
\hline & 相対変位 & 0.66 & 0.06 & 3.25 \\
\hline \multirow{4}{*}{$\begin{array}{c}\text { THO30-1FL } \\
\text { NS }\end{array}$} & 絶対加速度 & 0.25 & $-\cdots$ & - \\
\hline & 相対加速度 & 4.71 & 0.55 & 3.64 \\
\hline & 相対 速 度 & 0.63 & 0.11 & 3.23 \\
\hline & 相対変位 & 0.60 & 0.13 & 3.14 \\
\hline
\end{tabular}

ける絶対加速度, 相対加速度, 相対速度および相対変位 の水平成分，上下成分および回転成分の時刻歷応答を求 めた。ここで, 近似解の精度検討の 1 つとして, 得られ た近似解の全節点における各時刻歴応答の最大值を厳密 解のそれと比較する。表一 3 に全節点中で最も誤差の大 きい節点での誤差をそれぞれの最大誤差として示す。最 大誤差は, 全て $5 \%$ \%内であり, 非常によい精度が得ら

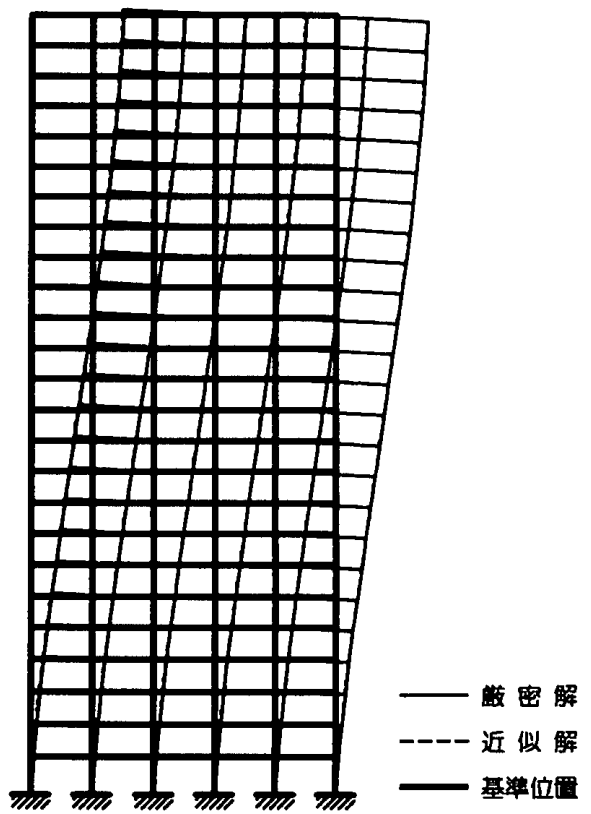

図一4 最大水平相対変位時(5.78 秒)におけるフレーム全体变形 (入力地震動：EL CENTRO NS )

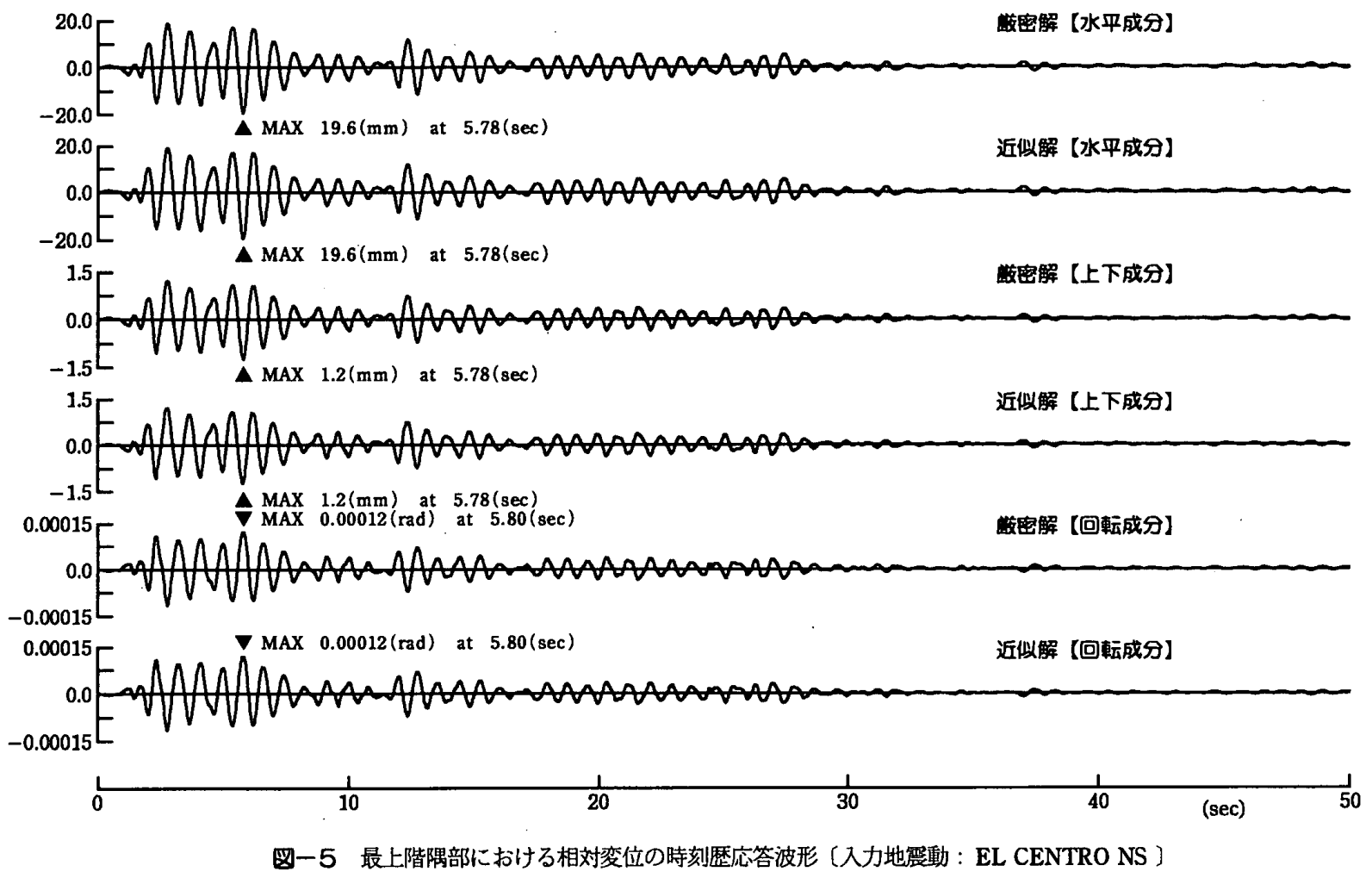


れた。図ー 4 にEL CENTRO NS地震動入力における最 大水平相対変位時(5.78秒)のフレーム全体変形を厳密解 は実線，近似解は破線で示す。厳密解および近似解のフ レーム全体変形は完全に一致している。また, 図ー 5 に 最上階隅部における厳密解および近似解の相対変位の水 平成分, 上下成分および回転成分の時刻歴応答波形を示 す。厳密解および近似解とも同時刻で最大值を示してお り，振幅，位相特性もよく一致している。

\section{3 地震時応力解析}

地震応答解析より得られた厳密解および近似解の絶対 加速度, 相対速度および相対変位を用いて, 全部材材端 の軸力, せん断力および曲げモーメントの時刻歴応答を 求めた。ここで, 近似解の精度検討の 1 つとして, 得ら れた近似解の全部材材端における各時刻歴応答の最大値 を厳密解のそれと比較する。なお，比較は各時刻歷応答 の最大值が, 部材の位置により大きく異なるため, 㛜密 解の梁および柱部材別の軸力, せん断力および曲げモ一 メントの各最大応力值に対して行う。表一 4 に全部材材 端中で最も鿁差の大きい部材材端での誤差をそれぞれの 最大愦差として示す。最大嚜差は, 全て $8 \%$ 以内であり,
非常によい精度が得られた。図－6にEL CENTRO NS 地震動入力における最大水平相対変位時(5.78秒)のフレ 一ム全体の軸力, せん断力および曲げモーメントを厳密 解は実線, 近似解は破線で示す。厳密解および近似解の フレーム全体の軸力, せん断力および曲げモーメントは よく一致している。また, 図ー7に 1 階隅柱柱脚におけ る厳密解および近似解の軸力, せん断力および曲げモ一 メントの時刻歷応答波形を示す。厳密解および近似解と も, 同時刻で最大值を示しており, 振偪, 位相特性むよ く一致している。

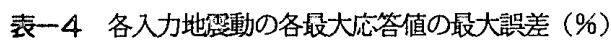

\begin{tabular}{c||c|c|c|c}
\hline 地 震 動 & 部材 & 軸力 & せん断力 & 曲げモーメント \\
\hline \hline \multirow{2}{*}{$\begin{array}{c}\text { EL CENTRO } \\
\text { NS }\end{array}$} & 梁 & 3.44 & 2.75 & 2.78 \\
\cline { 2 - 5 } & 柱 & 0.17 & 7.02 & 5.31 \\
\hline \multirow{2}{*}{ T A F T } & 梁 & 4.02 & 3.12 & 3.15 \\
\cline { 2 - 5 } EW & 柱 & 0.26 & 7.98 & 6.07 \\
\hline \multirow{2}{*}{$\begin{array}{c}\text { HACHINOHE } \\
\text { NS }\end{array}$} & 梁 & 3.67 & 2.52 & 2.46 \\
\cline { 2 - 5 } & 柱 & 0.21 & 6.37 & 4.69 \\
\hline THO30-1FL & 梁 & 3.60 & 2.62 & 2.62 \\
\cline { 2 - 5 } NS & 柱 & 0.23 & 6.62 & 4.98 \\
\hline
\end{tabular}

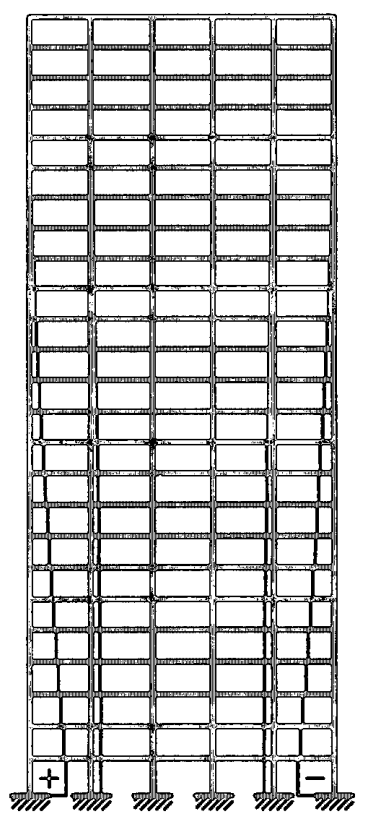

『軸力】

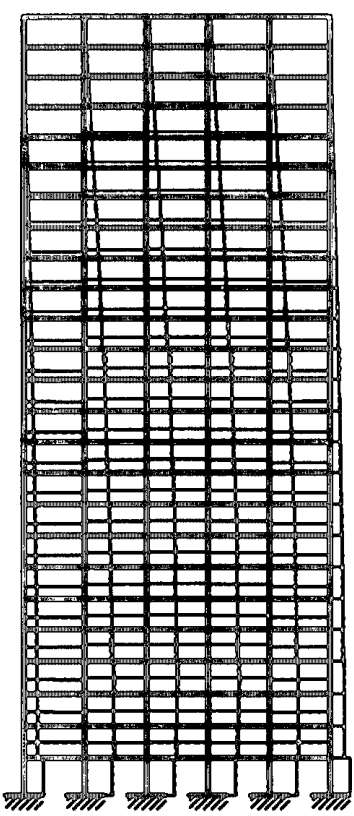

【せん断力】

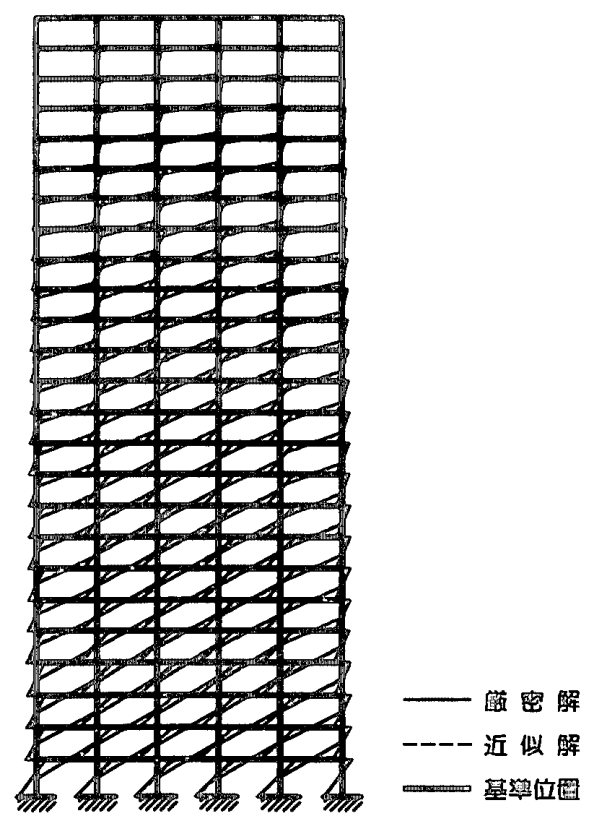

【曲げモーメント】

图一6 最大水平相対変位時(5.78 秒)におけるフレーム全体応力 (入力地動 : EL CENTRO NS )

\section{7. 结 論}

本論文で提案した動的縮小法およびモード置換を用い ることにより，低減後の未知数は，低減前に対して $2 \%$ となり，大幅な未知数の低減が可能となった。固有値解 析より得られた厳密解および近似解の固有周期は，よい 一致を示した。地震応答解析より得られた厳密解および 近似解の全節点における各時刻歴応答の最大值から, 厳
密解に対する近似解の最大誤差は，全て $5 \%$ 以内，また， 地震時応力解析より得られた厳密解および近似解の全部 材材端における各時刻歷応答の最大值から, 厳密解の各 最大応力值に対する最大䛊差は, 全て $8 \%$ 以内であり, 非常によい精度が得られた。さらに，地震応答解析に要 する解析時間は, 縮小および復元を含めて, 未知数低減 前の約 1 / 6 とかなりの時間短縮がなされた。 
したがって，建物の立体振動解析に適用可能な本解析 法は，少ない未知数で低減前の局部的な変形や部材レベ
ルでの応力を精度よく求めることができ，非常に有効な 解析法である。

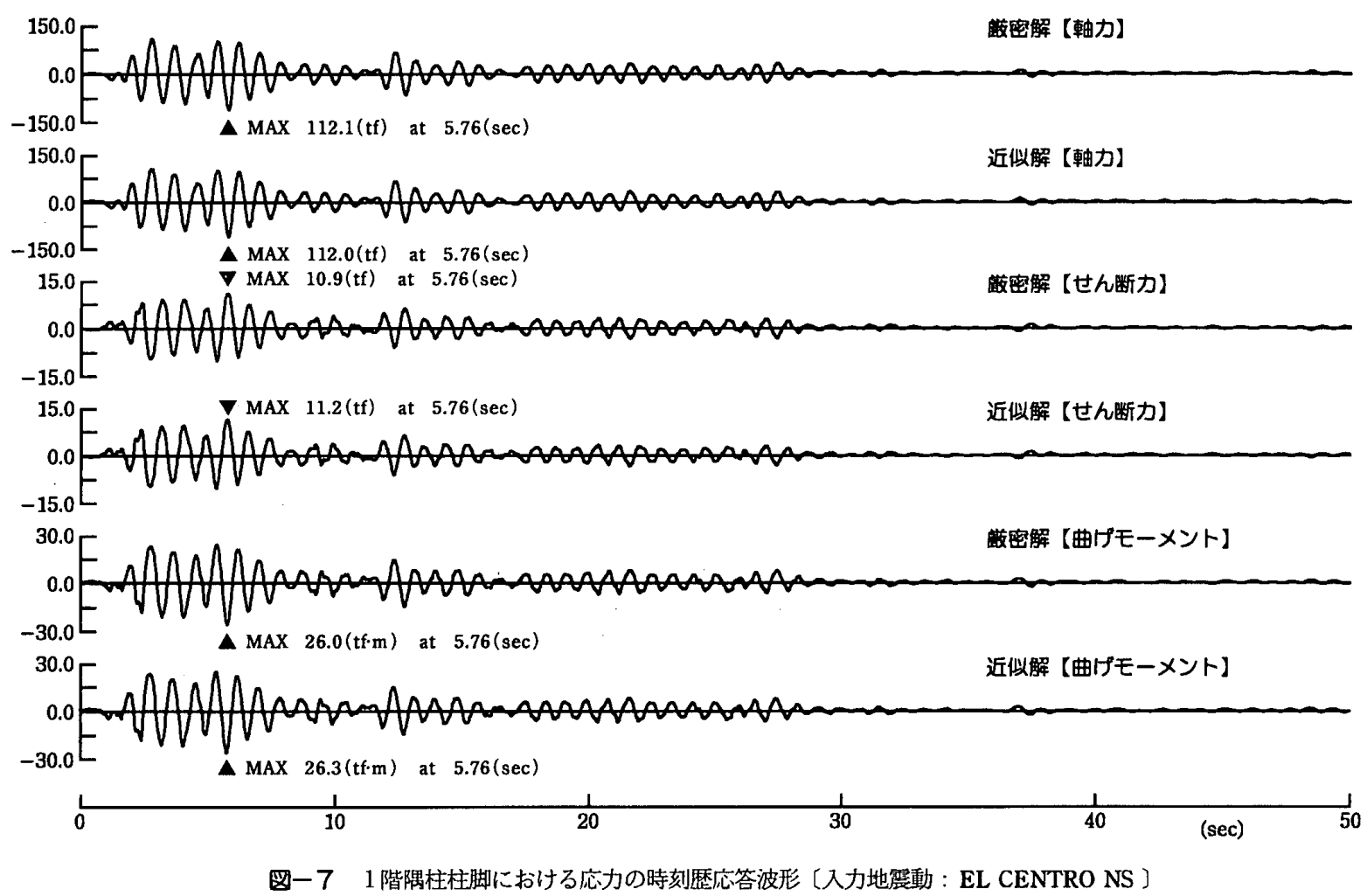

\section{参考文献}

1）富沢 稔，小西舱昭：柱の伸縮を考愿した多層多張間立体う ーメンのSHEAR-LAG-ANALOGYによる近似理論ーその 1 . D值法よりの抎張一，日本建築学会論文報告集，第 139 号， pp. $11-21,1967.9$

2）富沢 稳：歪エネルギーの凍結解凍の方法による柱伸縮ラー メンの近似解法（その1のI），日本建筑学会論文報告集， 第157号, pp. 27-31，1969.3

3）富沢 稔：歪エネルギーの凍結解凍の方法による柱伸樎ラー メンの近似解法（その1の II），日本建築学会論文報告集， 第158号, pp. 27-33，1969.4

4) 日本建築学会編：建築構造物の応力解析，丸善，pp. 125-145, 1977

5）日置興一郎，山中邦一，北野博己：反り変形を考えた棒理詥 による高層架構の解析一その 1 . 弾性静力学一, 日本建筑学 会論文報告集，第253号，pp. 51-57，1977.3

6）日㯰興一郎，北野博己：反り变形を考えた棒理諭による高層 架構の解析一その 2 . 弹性自由振動一, 日本建築学会論文報 告集, 第257号, pp. 31-38, 1977.7

7）藤井大地，藤谷意信：薄肉はり理論にもとつく立体高屏骨組 の有限要素解析法一薄肉はり置換法による高層ビルの構造解 析に関する研究(その 1$)$ - , 日本建築学会構造系論文埌告集 第453号, pp. 65-75, 1993.11

8）藤井大地, 藤谷義信：薄肉はり置換法の夷務構造設計への適 用に関する検討一薄肉はり置換法による高層ビルの構造解析 に関する研究 (その 2$)$ ），日本建築学会構造系諭文集， 第467号，pp. 45-53，1995.1
9）加藤史郎，菖蒲谷和孝，渡 祥弘：ポテンシャルエネルギー 最小の原理に基づき自由度を低減した骨組構造の解析，構造 工学論文集, Vol.41B，pp. 171-178，1995

10) Guyan, R. J. : Reduction of Stiffness and Mass Matrices, AIAA Journal, Vol. 3, No. 2, p. 380, 1965

11）長松昭男，大能政明：部分構造合成法，培風館，pp. 73-75, 1991

12）倉田光春：マトリックス構造解析法に関する一考察ーマトリ ックスの縮小法一，日本大学工学部学術研究報告会講演要旨 集. 第35回，pp. 155-158，1992

13）日本建築学会編：鉄筋コンクリート構造計算規準・同解説， 丸善, pp. 5-6, 1993

14）高層建築物構造評定委員会：高層建筑物の動的解析用地震動 について，ビルテイングレター, pp. 49-50, 1986.6

15）干葉正裕，池田昭男，倉田光春：建物の近似立体振動解析, 日本建築学会大会学術講演梗概集 B, pp. 391-392, 1993

16）千葉正㭲，倉田光春，松澤美広：建物の近似立体振動解析 一平面フレームの地震時応力の検討一，日本建築学会大会学 術講演梗概集 B，pp. 693-694，1994

17）千葉正裕，倉田光春，松澤美広：建物の近似立体振動解析 一高層平面フレームの地震時応力ー, 日本大学工学部紀要 A 第36巻，pp. 103-114， 1995

（1995年 5 月 1 日原稿受理， 1995 年 8 月15日採用決定） 